\section{Brandeis $\mid$ urear}

brandeis.edu/j-caste
CASTE: A Global Journal on Social Exclusion

Vol. 2 No. I pp. $30-46$

April 2021

ISSN 2639-4928

DOI: $10.26812 /$ caste.v2i1.265

\title{
Fracturing the Historical Continuity on Truth: Jotiba Phule in the Quest for Personhood of Shudras
}

\author{
Snehashish Das'
}

\begin{abstract}
Anti-caste traditions in India work to understand and examine the idea of personhood which the majority in India is deprived of by virtue of being born in the lower rungs of the caste hierarchy. This paper examines the historical continuity in Brahminism and the rupture Jotiba Phule presents to it through his art and activism which serves to disturb the regular flow of singular continuity of what is perceived as history and historiography. Jotiba's quest is for finding the essence/personhood of, what Butler calls, a 'precarious subject' and recognizing that precarious subject - the Shudra, as a subject of history. But the personhood of this precarious subject is never a complete personhood. Therefore, Jotiba attempts to unveil the path towards achieving complete personhood which is embedded in reaffirming the lost or concealed truth - by discontinuing the historical flow of the social structure of caste and establishing a new subject rising out of crisis in social structure in history. I have chosen two works from Jotiba's works as new methodological tools for history writing and historical criticism, and made hermeneutical and phenomenological readings of the both. The works are his poem Kulambin (a peasant woman), and the Satyashodhak (truth-seeker) marriage as the public performance of protestas they are both - the essential and the mundane to his life, which exemplifies the truth Jotiba followed and established an organization Satyashodhak Samaj (Society of Truth Seekers) as a testament to it.
\end{abstract}

\section{Keywords}

Jotiba Phule, personhood, precarity, performativity, continuity, Satyashodhak, Shudra.

\footnotetext{
'Ph.D Scholar, Centre for the Study of Social Systems, Jawaharlal Nehru University, New Delhi E-mail:mx.snehashish@gmail.com
} 


\section{Introduction}

Jotirao Govindrao Phule, alias Jotiba Phule, is associated with the renaissance in Indian history; considered to be the father of modern India, and endearingly called Mahatma (great soul) within anti-caste traditions. This paper does not wish to and cannot introduce Jotiba to academia. For in the politics of introduction, I encounter three dilemmas: one, who shall I introduce Jotiba to; second, what is the relevance of 'I' to introduce Jotiba; and third, when do I know what is truly and justifiably introducing such a figure who challenges the course of continuity? Introducing Jotiba to masses in words means creating a readership of masses- as Jotiba Phule (1991b, pp. 22-23) advocated a system of 'mass education' wherein the state must encourage mass education from the primary level to engender quality education of the masses at higher levels. But living the life of 'contradiction', as Ambedkar (Round Table India, 2016) puts it, between political equality and inequality in social and economic life in India, mass education or even enrolment in higher education remains a distant dream. ${ }^{1}$

Introducing Jotiba through the text essentially means introducing him to those who have access to education and interest in anti-caste scholarships. Among the masses, some have known, read, and educated themselves with his works, many have lived the life Jotiba lived and represented, and experienced the truth that he had experienced and sought. But to introduce Jotiba to them begets the second question: Who am 'I' to introduce? Several activists and academics have read or, are familiar with Jotiba's text Slavery (1991), but a major part of his texts remains unread and unexplored, and much more is untranslated. Reading Jotiba has made me think that he stands as an epitome of truth in the kind of history or the social matrix we are eager to read about. Jotiba himself, and only himself can be the entry point to introducing Jotiba. As a reader and a researcher, I can only introduce my thoughts on Jotiba or his specific works, rather than the vastness of Jotiba, his life, works and thoughts that are hitherto unexplored widely.

It would be an injustice to Jotiba to write about him and call it an introduction to him. This leads to my third point: that is, to introduce someone, one needs to know where to enter their life and work, only then can one follow the truth of their personhood thereafter. One may argue that the entry point to Jotiba's life can be the event, in 1848, when he was humiliated and abused at his Brahmin friend's marriage (Phule, 1991a, p. xvi) and experienced the truth of his birth and life, of Brahminism, ${ }^{2}$ in that very moment, and the truth followed. But that is somehow untrue because the experience of truth in his life precedes that event as much as it follows it.

One can pick any moment of his life and work and find out that the truth is happening; truth, one can say, in simpler sense, is the essence of one's being. For a

${ }^{1}$ Official record states that the Scheduled Castes (SCs), Scheduled Tribes (STs) and Other Backward Classes (OBCs) are represented in 14.9 percent, 5.5 percent and 36.3 percent, respectively, of total enrolment in higher education as against 15 percent, 7.5 percent, and 27 percent reservation, respectively, mandated by the Constitution of India. Only 5.2 percent of total enrolment belongs to Muslim minority, and 2.3 percent belongs to other minority communities. Out of the total enrolment 51.36 percent are male, and rest 48.64 percent are female students. See the report of All India Survey on Higher Education 2018-19, Department of Higher Education, Ministry of Human Resources Development, Government of India, 2019.

${ }^{2}$ Dr. B.R. Ambedkar defines Brahminism as 'the negation of the spirit of liberty, equality and fraternity. In that sense it is rampant in all classes and is not confined to the Brahmins alone, though they have been the originators of it' (reported in Times of India, February 14, 1938). 
person, it can be argued, that the truth is the purpose of living - happens in the very moment a person experiences and realizes what they are supposed to do or become, and that moment is unique. One can pick any such moment from his life and begin understanding Jotiba there onwards. He was admiringly called the 'embodiment of truth' by his wife Savitribai. ${ }^{3}$ His quest for truth translated into the Satyashodhak Samaj or the Truth Seekers' Society ${ }^{4}$ that he created. Thus, instead of introducing Jotiba, what my scholarship will essentially do is analyze two of his works: one, a poem Kulambin ${ }^{5}$ or a peasant woman; second, the Satyashodhak marriage that he pioneered. These will help me and others understand both the simplicity and vastness of truth. This paper, throughout its length, tries to explore the concepts of 'truth', 'history' and 'personhood', from my hermeneutical and phenomenological readings of and from the works of Jotiba. Such scholarship, beyond mere introduction, is essential as it challenges the continuity of Indian scholarship which is predominantly Brahminical, and hegemonized by the Brahmins and other twice-born ${ }^{6}$ castes.

\section{Art, Methodology of History and the Subject of Recognizability}

I have given some time to think over Jotiba's poem Kulambin, a peasant woman, (Damle, 2014) which I read as one of those moments in Jotiba's life and work which not only has an encounter with truth but also brings forth that truth to the public through art. The poem is based on a peasant woman, who is essentially a Shudra ${ }^{7}$ and utterly anonymous. This namelessness or anonymity of the subject makes the poem seem a work of fiction, around a fictional character, as it is neither a case study nor a biography. It leaves us with the methodological questions - can fiction be a form of historiography? Can fictitious subjects be a subject of history? Can an event which might not have actually occurred in the past but carries an idea or sense about and from the past, hold truth value in writing history? History is often understood to be not just an idea about the past, but a systematic record of the past; a verifiable record that appears in form of Annals and Chronicles. This is the essential line that traditionally segregates history from myth. Thus, the established idea of history and historiography

\footnotetext{
${ }^{3}$ See Sabrang (2016), To Jyotiba, from Savitribai Phule: these aren't love letters, but tell you what love is all about, Scroll. Retrieved 16 September, 2020, from http://scroll.in/article/801848/tojyotiba-from-savitribai-phule-these-arent-love-letters-but-tell-you-what-love-is-all-about.

${ }^{4}$ Satyashodhak Samaj was established in 1827 having Jotirao Phule as its first President and Treasurer. The main objectives of the organization were to liberate the Shudras and Ati-Shudras, and to prevent exploitation by Brahmins and other 'upper-castes'.

${ }^{5}$ Kulambin, that refers to a peasant woman in this poem, also can mean a female domestic help. The word is a rude and scornful term. The poem was published in a periodical titled 'Dinbandhu' which was founded by Krishnarao Pandurang Bhalekar in 1877, to serve as the mouthpiece of Satyashodhak Samaj.

${ }^{6}$ Castes those fall under Brahmin, Kshatriya and Vaishya Varnas are considered to be the twiceborn or Dvija castes in Varna hierarchy, as they perform a ceremony called Upanayana where they enter into the life of Hinduism which is considered to be the rebirth. Shudras even though fall under Varna hierarchy, still are not considered to be the twice-born.

${ }^{7}$ Shudra constitutes the lowest rung in the Varna hierarchy. They are traditionally linked to the service castes, such as peasantry, artisanship, etc. Majority population in India falls under Shudra Varna, and most of the caste groups under Shudra Varna are officially (in the constitution) categorized as Other Backward Classes (OBC) in India.
} 
pushes ambiguous subjects from the past to the periphery. So, can Jotiba's poem be considered history? Here, I shall argue that his poem should not be considered just any form of history writing, but a challenge to the course of continuity of history writing, in other words, a historical criticism; a 'fracture.' To explore that, we shall analyze the relationship between history and truth here onwards.

What was it that made Jotiba have a peasant woman in his work of art- a character who was never thought of being worthy of being recorded as a subject in the history of India? If one looks into the nineteenth or early twentieth century, art had a religious (read caste) and royal value. But by saying this I do not mean that the 'lower castes' did not have any art form of their own; rather those cultural or artistic forms did not have the recognizability to be introduced as pious and royal as 'art' and 'aesthetic' - to be worthy of being written down, documented, or presented to the secular public. But Jotiba was one of the very first of those few 'lower caste' artists whose art is not just an oral tradition, but breached his caste groups to reach the secular public. At a time when recognizable artwork was reduced to artworks on kings, queens, and the Hindu deities, how could a subject of stigma; an embodiment of pollution; a subject marked by humiliation and violence; a wretched and undesirable body break the chains of piousness (caste purity) of artwork.

Thinking through Butler's (2009) idea of 'subject of recognizability', the subject is someone who is placed within the established norms of being of a thinking being; the embodiment of ideal personhood. The agency of personhood and thought are produced within the social structure through the historical allocation of power. We can think of another artist around the same time as Jotiba, and think about the truth of the very subject of his artworks and the truth it established or presented to the masses, i.e., Raja Ravi Verma. He was a Brahmin, a royal painter who also gradually became a Hindu spiritual painter, painting the everydayness of an 'upper caste' woman as subject. The subjects of many of his paintings are kings and queens, including Maharaja Sayaji Rao of Baroda (1881), Maharani Chimnabai of Baroda (1881), Rai Pannalal Mehta who was the Dewan of Udaipur (1901), Maharani Karthika Thirunal Lakshmi Bayi of Travancore (1887), alongside others. Verma even recorded historical events; painted the 3rd Duke of Buckingham being greeted by Maharaja Ayilyam Thirunal and Visakham Thirunal of Travancore (1880). These are considered to be history because they are not nameless; they present a systematic record of history- the sort we can term as annals on the canvases. This leaves us an inquiry in the nature of a history that makes such figures the subject of that history; the true subject - thus linking history to truth. The subject of history always emerges within history, and then history is written around that subject - which marks the arrival of a history and subjects a cyclical process, wherein subject and history remain the product of power within the social, political and historical landscape. But Jotiba, I argue, is the one who turns that power relation upside down.

\section{Historiography and the Precarious Body}

If we examine the Indian history, it is not an idea of India as merely a form or an entity or a state being a thing/'something' that we aim to understand. It is the very subject within the premise of the Indian history that constitutes the history of India and the subject is not any subject, but the subject of essence that gives us an idea of India. What is essential or unique about India that constitutes history (of India) rather 
than the nominal idea of India or a mere description of India without essence/value of India - which makes history (of India) about the truth (about India). What we understand from Raja Ravi Verma's artworks, it is the kings and queens or the Hindu mythical figures arriving in history which constitute the truth in history, that define the essence of history through his paintings. Drawing from Hayden White's (1980) critiques of annals against proper history, where he inquires into and critiques Annals of Saint Gall, we can argue that even Verma's annals do not essentially say anything about the prevailing social system, legal boundaries and subjects, and the moral codes of the state and society. Yet, the mere situating of kings, queens and deities in the course of time as essential reflects the truth about India in Verma's artworks. The same applies to certain historical events painted by him, which are as relevant as if they never happened, as they have no description of them, and no transgression of the political-moral code attached to them. They are made essential by merely situating in a certain time in the past. Jotiba's poem on the peasant woman essentially questions this continuity on truth in writing history employing the form of writing as White (1980, p. 27) proposes 'value attached to narrativity'. Reading Jotiba, we understand that such truth is either a partial-truth or truth as falsehood in history making.

A peasant was never thought worthy of being a subject. She who had been invisible from the popular imagination of artwork became the primary subject in Jotiba's art. The peasant woman was invisible especially because of her being on the earth, her epistemic position, and the banality of her life. Especially because she lives a banal life, her mere presence on earth, her mere appearance are the reasons for her 'invisibility' and not being considered as a subject. She was considered to be a being without an essence; where essence is found only in the being and artworks of kings and queens, temples and the Hindu figures, which are essential because they are marked differently. This is precisely resonant in the contemporary merit debate that ignores how caste governs people's lives.

But in choosing the subject of his poem, Kulambin, Jotiba reaches to the specifics; from nation to region, region to local, and finally from local to caste. That is what I call the moment of truth happening; truth, when you bring it out from its invisibility, reveal that it is happening. Indeed, for Jotiba, her being is invisible because her merit or essence is invisible as she is rendered banal by the force of history. By this force of history, as Jotiba narrates, the bodily violence and humiliation she has undergone establishes her as a sexually/bodily insignificant or governed being. If we see Raja Ravi Verma's paintings of the Maharashtrian Lady (1893) or Lady with a Fruit (1880) or The Bombay Strongstress (1893), etc., these can fundamentally be distinguished as 'upper-caste' women by their mere appearance from the saree they wear, the ornaments they adorn, the palaces they reside in, and other cultural markers which the subjects and portraits are inscribed with - they are deemed sexually significant. But a Shudra woman, as Jotiba writes, cannot afford to deck her house with the sacred Tulsi (basil) leaves, plait her hair, or adorn herself beyond her coarse saree and the sweat of her toils. A Brahmin woman, flaunting her ornaments, has never applied fragrant scrub to a Shudra woman, does not bathe her, does not comb her hair, does not make her face up, so Jotiba writes in the poem. A Brahmin woman, despite being another oppressed subject of the Brahminical patriarchy, ${ }^{8}$ had no sympathy or care for a Shudra woman.

${ }^{8}$ Brahminical patriarchy is based on the idea that the mechanism of caste is based on and thrives upon the patriarchal system. Ambedkar theorizes how endogamy, sati, mandatory widowhood, 
In several chapters in the Collected Works of Mahatma Jotirao Phule Vol II translated by Barrister P. G. Patil (1991), he mentions that Jotiba writes about the punishment a Shudra has to go through at the hands of Brahmins. The condemned have to face severe physical injuries - they are whipped, maimed, mutilated, have had pincers applied to their genitals - and yet the punishment does not stop. While injured, they are treated with pain by having saline water, often boiling, poured over their wounds, until finally many succumb to the injuries. The women are forced to inhale the smoke of chillies burnt under their faces; many times, the Brahmins violate their modesty, molest, torture, and rape them to manifest their authority over the Shudras bodies. Jotiba writes that many Shudras were semi-naked most of the time, barefooted or forced to hide their naked bodies with tattered cloth throughout the year. But at the same time the 'upper castes', from Marwari to Brahmins, lived 'respectable lives', wore good clothes, turbans on head, draped their bodies with new sarees and gold ornaments.

What does the violence imprinted on a Shudra body make of her? Can she be a subject of recognizability under such condition of, what Butler (2009) calls, 'precarity'? Can her body be considered worth of essence, of grace, of beauty, of desirability, of respectability, of sexualness which can mark her as a being within the norms of personhood, of thought and agency? The questions of who has the right and accessibility to justice, who is criminalized for their mere being, who is stigmatized, how their body appears to the secular public, on what limits of normative body and personhood the person exists historically serves to decide who can become a recognizable subject of politics and art.

\section{Reaffirmation of (Shudra) Personhood in Precarious Body}

Jotiba, portrays the everydayness of the peasant woman, how she collects cow dung and carries it in a basket, how she cooks, goes to the field, works relentlessly, gives food to beggars and ascetic Brahmins, fetches water, makes cow-dung cakes for cooking, mows and sells grass and weeds, feeds cattle, and harvests, collects and sells crops. In addition to that, Jotiba describes that she is a singer, who sings in the morning and wakes her husband up. At that moment of realizing the truth about the Shudra peasant woman, Jotiba reveres her as an industrious woman; a meritorious woman; a hardworking woman of worth, who the Brahmins stigmatize, call ignoble, and humiliate ignoring her merit. Even amidst violence, pain and precarities which dehumanize a Shudra woman and delegitimize her personhood and life-possibilities, Jotiba discovers merit in her. He finds the essence for her subject-hood, which is truly unique.

Jotiba reaffirms the personhood she has been robbed off through his poem. He asks if a Brahmin woman is worth such merit; can she do the labour that a Shudra woman does, can she nurture without discrimination, can she have such productive power, such essence, and thus, personhood? So, this poem brings forth the essence of the peasant woman to the world. It is similar to how Heidegger (1977) sees Van

etc. which are the reason for women's oppression in India are meant to maintain caste purity and lineage. Ambedkar and other anti-caste thinkers also highlight how Manu Smriti and other Hindu scriptures are by essence patriarchal. See Dr. B.R. Ambedkar (1979), Castes in India: their mechanism, genesis and development. In Dr. Babasaheb Ambedkar Writings and Speeches Vol. 01, (V. Moon, Ed.). 
Gogh's painting of the shoes of the farmer. Through Jotiba's poem the peasant woman moves from her house to the muddy field and the market, through all hurdles and problems, with starvation, without care, with humiliation, and stigma, and still finally produces merit or essence from what is deemed a banal life. Jotiba asserts that despite these precarities she still has a personhood which merits a subject of recognizability. He avers that without all luxuries, that are allowed to a Brahmin woman and which make her a visible and recognizable subject, a Shudra woman still nurtures nature and society unlike her Brahmin counterpart. Through the poem, the truth of the Shudra woman moves from invisibility to visibility, from earth to world. And this moment where the peasant woman becomes the subject of the poem, I consider a historical moment happening within history- a moment when truth is revealed - the truth of the peasant woman herself and the truth of history, of India, of Maharashtra, and of caste. Such subjectivation is not just mere essentialization of presence of a person or an event in history, but an attempt to tell a story around it that explains the social system, ethical and moral codes about the prevailing society.

\section{Discontinuity in History and the Recognizability of the Precarious Subject}

Returning to the question I asked if the fictional nameless peasant woman can be a historical figure; I believe the nameless subject being contested with the name-affirmed subjects like kings and queens marks a historical change or movement in the continuity of writing of history. The peasant woman is not just 'a woman'; she is every, or most, peasant women. Thus, Kulambin presents a collective resistance against the norms of history writing; against norms that make one eligible to be recognized as subject - of art, history and politics. The peasant woman might appear to be fictional, but there is a 'truth' value to her, especially because Jotiba, as the poet and a real person from history, is the witness to her (and of all/most peasant women's) truth. In this way the subject transcends from the appearance of being fictional to being a truly historically constituted subject. This new sense of history writing where we situate Jotiba's work is very similar to Hayden White's (1978) proposition of structuring history in literary forms, through different types 'emplotments' like tragedy, comedy and romance, for better understanding and comprehension of the past. While White proposed a type of history writing through literature in which one can distinguish 'reality' from imaginations or ideological prejudices for better sense of the past, through the use of figurative languages. Today, if our understanding of historiography can accommodate Jotiba's works, it will be of a kind wherein truth shall be distinguishable and achievable. In a way, Jotiba's works lead us towards historical criticism, by asserting that history and historiography goes beyond 'ordered facts', and is complexly associated with literature produced within a historical landscape.

The truth represented through the royal painting is only a partial truth especially because the truth of royal members, or of the 'upper castes' cannot be truly revealed in the absence of the truth of the peasant woman. Jotiba (Phule, 1991a, p. 76) has also written ballads of royal persons like Chhatrapati Shivaji Raje Bhonsle, but such songs of glory have been written with the presence of the Shudras and the AtiShudras as subjects. One such ballad is especially about the good work Shivaji has done for the Shudras and the Ati-Shudras; and thus, the King becomes the nominal subject and the masses under his rule are primary. Both Kulambini and the ballads of 
Chhatrapati Shivaji Raje Bhonsle are firmly opposite to how the truth is represented in other royal artworks like those of Raja Ravi Verma, in normative history; where Jotiba takes a moral and political stand about the narrative, where story gets a closure, about his central subject while essentializing unlike Raja Ravi Verma. A reaffirmation of personhood to a precarious body, as a political- moral stand, challenged how one saw a subject and subject-hood in art, history, and politics. Yet, the peasant woman is a precarious body, her personhood is not at its full potential. So, what Jotiba does to challenge these conditions of precarity of a Shudra subject, I discuss in the subsequent section by analyzing his brainchild, i.e., the Satyashodhak marriage.

\section{Rejecting the 'Brahmin Oedipus', so Precarious Subjecthood}

Earlier, I proposed that truth in history is also falsehood in history making, as another idea of truth (of India, ilk) is represented through artworks of the Hindu mythical figures turning into historical ones - which Jotiba believes to be falsehoods and deceptions. If the idea of India or essence or truth of India is represented through the Hindu mythological figures, then there is a need to revisit how Jotiba understands history. In Gulamgiri or Slavery (1991b), through examples of the Hindu mythological figures, like Parashurama, Brahma, Vamana, Varaha, Narasimha, and so on, Jotiba argues that these figures are essentially the Brahmin Oedipus; ${ }^{9}$, historical personas of proud, cunning, and cruel Aryan Brahmins, who took over the majesty of one true God conquering this land (Kshetras) and massacring, oppressing, and enslaving the protectors of the land (Kshatriyas/Rakshaks) and turning them into Kshudras or Shudras (insignificant) (1991a, p. 132) - turned into appearingly real and glorious personalities - as earth-gods eventually. In his books, Jotiba uses rationality as a method to subject the Brahminical texts to rational questions, and then insults them as the texts are rooted in lies and in violence, discrimination, and subjugation of the Shudras and the Ati-Shudras, based on conquest of their homeland, and as something can be reasoned as deceptions or lies - far from being truth or close to it; this method is termed by Soumyabrata Choudhury (2017) as the 'rational insult'. If they represent what is essential in history, then history will always condemn or invisibilize the Shudras and the Ati-Shudras who are the 'original inhabitants' of India and the subject themselves will be constituted of falsehood as the earth-gods are the construction of false myths, blasphemy, wrong idea about God, deception created by the Brahmins and the Brahmin Oedipus.

For Jotiba the idea of earth-gods is, as we can interpret, of no higher moral beings to represent truth, but a supernatural and mythical manifestation of the Brahminical human society itself- is born out of the Brahmin treachery; pompousness is the main reason for the enslavement of the Shudras, it is the main reason for the violence they are subjected to and why they even fail to revolt against because of mental enslavement. Here, Jotiba does not try to reaffirm the personhood of a precarious body unlike in the first instance, rather he moves a step ahead to change the course of history and tries to

${ }^{9}$ Oedipus Rex, is a character from Greek mythology, popularly referred in Freudian psychoanalytic concept. 'Oedipus complex' is a psychosexual stage of development where a child experiences desires towards their opposite sex-parent and envy for the same-sex parent, as Oedipus killed his father Lauis and married his mother Jocasta by ignoring and trying to escape the prophecy. But here, I am using the term 'Oedipus' as a reference to ignorance, or wilful divergence from truth, and the sense of pride and superiority of knowledge, of selfhood, not just over the rest of humanity, but also over God. 
reject the very entity that causes the Shudras' precarity, so that they can achieve their personhood with full potential. And for him truth cannot be something unjust, it cannot be the reason of slavery. If it is, then it is manipulated by falsehood. Thus, what he demanded is a peasant cultural revolution to bring out the true potential of the truth.

Through cultural education of the peasants, when they regain a sense of pride attached to their past identity, to the land, and reject the Brahmin's treacherous and deceptive myths and godly figures that will bring the truth to fore. The peasant becomes a new subject in formation, a counter affirmation of identity, and a sense of truth occurs with the arrival of this identity into history and politics, and also justice is done to the historical wrongs. Thus, it is not merely the act of history writing that is linked to the truth, but it is the ideology of history that has to do with the truth. His whole work is about passing correctness to continuing truth, to save it from falsehood, and as Jotiba passes correctness to the truth, not just seeing, apprehending, reasoning and (dis)confirming it, this transforms him into a philosopher. For I and the readers, to recognize Jotiba as a philosopher is also discontinuing the history of philosophy which is rooted in the bias towards Plato's Philosopher-King. ${ }^{10}$

\section{The Truth Question and the Full Potential of Personhood}

Jotiba's attempt of liberating the Shudras from caste slavery to achieve full potential of their personhood, which is intimately linked to their being the subject of recognizability, was not just limited to highlight and reject the untruth and deception affirmed by the idea of earth-gods in Hinduism, but to understand and submit to the truth to mark a sense of emancipation. He believed that if falsehood or manipulation of truth is the reason for slavery, then the real truth would lead to liberation. The method he used to find out the truth is reason. He reasoned and believed that God cannot be multiple, but one; formless, and omnipresent. He reasoned that there exists an intimate relationship between God and humans; like that of parents and children since God is the creator of all beings in the world (Phule, 1991a, p. xix). And this reason brought a fight against priestcraft, as he believed one does not need any intermediary to reach to God, a practice fundamental to Brahminism. He believed, 'it is a universal truth that fraternal religion has no place for mutual oppression' (Phule, 1991b, p. 24). For Jotiba, the Brahmins have kept the depressed and downtrodden ignorant of their human rights and God has bestowed freedom to all people to enjoy equitably all the things created on the earth. A truly liberated human being cannot hesitate to demand these (Ibid., p. 25).

We can unarguably say that Jotiba was the first person in modern India to theorize an Anti-Caste Liberation Theology within the monotheistic traditions that developed across the world, as he critically thought of the idea of theos in terms of liberation of the Shudra and the Ati-Shudras, similar to what has developed in the context of the oppressed people across the world. He has compared Jesus Christ with Baliraja (Ibid., pp. 60-62), who he considers as the glorious indigenous king of India who has appeared in the Hindu myth. He also wrote a na at (Praise of Prophet Muhammad)

\footnotetext{
${ }^{10}$ In Plato's (1968) Republic, he asserts that a king must be a philosopher as against the tradespersons, crafts-persons, who were slaves in the ancient Greek society, and must be tricked into believing that they are naturally assigned their role in the social hierarchy in order to maintain the social order. They must be followers of the philosopher-king as they have naturally no time and role for doing philosophy.
} 
(Omvedt, 2011), and praised Buddhism alongside Christianity and Islam as potent means to emancipate humanity from social inequality (Kale, 2020).

\section{Satyashodhak Samaj and Activism}

Jotiba did not limit this philosophy to just himself or his personal beliefs; he institutionalized it into a movement, in building a truly emancipated community whose quest for truth opens ways to achieve their lost or invaded personhood. Thus, Satyashodhak Samaj bloomed in 1873 and all members had faith in the philosophy Jotiba espoused - equality, freedom and fraternity (Phule, 1991a, p. xix). The preachers of Satyashodhaks wore a turban, dhoti ${ }^{11}$ and a blanket, paired with drums in hand (Bhadru, 2002, p. 852) which signified how they tried to subvert the norms of body through visibility, by wearing the respectable clothe those entitled to only the 'upper castes' against the half-naked body they were supposed to bear. Of course, it would be possible to unconceal and reaffirm the unacknowledged merit or essence or personhood of precarious body(ies) and reallocate the recognizability through an artwork, but to reject the precarity in toto needs more than artwork; it needs activism, an organized movement and an institution - an interpersonal engagement.

One of the significant works the Satyashodhaks did was revolutionizing the idea of marriage. Jotiba (Phule, 1991a, p. 67) advises in one of his Abhangas $^{12}$ not to rely on the Brahmin priests and instead to choose referees from one's caste; from among juniors, seniors, and friends of both the parties in a marriage. Jotiba advocated simple and inexpensive marriages between two parties having mutual affection, examining essential points, such as age and temperament. The couples should offer prayer to the only truth, i.e., God, the creator, garland each other and celebrate their marriage. Jotiba also opposed child marriages and supported widow remarriages and inter-caste marriages.

But what was the significance of the Satyashodhak marriage? The Brahminical marriage or partnership was not essentially about love or affection or celebration, or else it would not be limited by the boundary of endogamy. Marriage under Brahminism was about production of caste and caste lineage, and to maintain its historical continuity. Marriage was another, yet most essential way, of reinforcing caste slavery on the Shudras since it was only recognized as legitimate with the presence of priestcraft and remained a burden to the poor as it was conducted in the most expensive manner possible.

Jotiba Phule (Ibid., pp. 115-116) in his opinion, on a note by Mr. B.M. Malabari, on infant marriages wrote about the suffering of an infant girl in the process of marriage as she has no place which belongs to her, and is burdened with work and responsibilities from a young age, never taken care of, abused, deprived of education and employment, and vulnerable to premature deaths or forced to commit suicide - a condition Jotiba compared with the American slaves. Jotiba Phule (Ibid., pp. 117118) also comments on enforced widowhood where a woman is again de-humanized, desexualized, forced to shave her head, improperly clothed and fed, not allowed to join any celebrations, marriages and religious ceremonies, stripped off ornaments, and also at times raped, and consequently shamed for having children. This targeted violence on women's lives, sexuality, and personhood happens as part of custom, for the benefit,

${ }^{11}$ Traditional Indian men's wear- unstitched cloth wrapped round the legs in various styles.

${ }^{12}$ Devotional poetry or hymns, literally translates as 'non-ending' or 'flawless'. 
pleasure, and the lust of the Brahmins, and preserves the power of Brahmin men over the sexuality of both 'upper-caste' women, as well as 'lower-caste' men and women, to perpetuate caste in every aspect of life, sexualness, and marriage.

Satyashodhak marriage was revolutionary as it offered choice to people to marry; it introduced the concept of love and affection into their lives, thus gave them an agency to express their personhood independently. They believed a true partnership could not be established upon the foundation of violence and subordination. And to achieve that Jotiba influenced and made associations of the oppressed across castes and genders to help liberate them from compelled servitude to the Brahmins / upper castes and Brahminical causes, as written in Dharmasutras and Manusmriti that Ambedkar (1990, pp. 52-54) has exposed, which was the only way Shudrahood was constituted. For example, Satyashodhak couples educated and organized a protest of the Nai (barbers) caste against shaving heads of women who lost their husbands (Bhadru, 2002, pp. 849-850). Jotiba's son, Yashwant, was also married the Satyashodhak way.

When we can think through Friedrich Engels's (1902) origin of family, institutionalized relationships, vis-à-vis marriage, and also through feminist discourses and scholarships around the same, we can understand how these very institutions have been imagined upon women's subordination and accumulation of private property. But within the hierarchy of caste, the 'lower castes' are majorly and traditionally deprived of superfluous wealth, and the social and religious rights to achieve it (Phule, 1991b, p. 20). While Jotiba to Ambedkar and present feminist scholarships are in consensus that within the Brahminical social system marriage is a tool of women's oppression, still on the solution line, their paths diverge. A minority voice, especially of trans*-queer persons, has called for abolition of the institution of marriage which the mainstream discourse has failed to recognize. On the other hand, while the right to love, the right to desire is not allowed to 'lower castes' and other marginalized sections, even in today's time, we remember many couples, like Shankar and Kausalya, Pranay and Amrutha, who endeavoured to marry of their choice outside their castes and were brutally murdered or subjected to brutal violence (BBC, 2018), while many others waged legal battles to achieve their right to love and marry, like Hadiya and Shafin (Chandrachud, 2018). Many have called for inter-caste, inter-faith marriages, and alternative institutionalized forms of marriages like the 'self-respect marriage movement' of E. V. Ramasamy Periyar, and 'Satyashodhak marriages' which were materialized to dismantle the Brahminical form of marriage that is rooted in the idea of oppression. The question stands: Could individual and autonomous partnerships based on love, choice, and freedom without having the institution of and around marriage be as revolutionary in achieving the personhood of the Shudras? Can we do away with institutions altogether, as some have argued in today's time? Could Jotiba have done so? To find an answer to this, one must revisit the historical discontinuity that happened to the truth-value of marriage by the Satyashodhaks and how they achieved it.

\section{Historical Discontinuity and the Emergence of the New Performative}

Marriage is essentially an ontological truth - a truth in itself. It is an ontological truth especially because it is not a physical truth; one cannot prove through their body or through their sensory motors that they are married. Yet by pronouncing 
words / mantras, which are called mangalashtake, making promises one actually lives the life of a married person, obligated to fulfil all the promises they made during the marriage ceremony, bound by the fundamental ideology and norms of it, even without any corporeal transformation. Looking through the lens of Austin's (1962) 'performativity', a marriage even though unverifiable, is an ontological truth because through the ceremony and rituals the truth of marriage happens in essence. However, in the Brahminical form of marriage there is a ritual coercion; it did not have absolute participation and thus it lacked the very essence or truth value. Brahminic form of marriage was based on the idea of a certain kind of survivability in the Brahminical social structure which actually faced a historical challenge and discontinuity by the Satyashodhak marriage where truth was perceived as beyond survivability; in participation.

The Satyashodhak marriage can be considered a new performative - if not a unique performative as it does not exist in the singularity of the event, even if the first marriage is unique in history, it is still part of 'iterability', as Derrida (1988) puts it, of the very event. Even the first Satyashodhak marriage belongs to the structural repetition of it, thus it is not unique, but new - as it brings a novelty to the idea of marriage and a new identity around that discourse. The Satyashodhak marriage happened as a new performative due to both historical crisis in the social structure and loss of personhood under Brahminism; also, with the need and scope for creating a new exceptional identity, a conscious identity which is historically specific - marking a discontinuity in the flow of history. And this is the Derridean notion that 'iteration'/ repetition produces legitimacy to the exceptional identity through the discourse of that identity - as it suggests the production of a range of the same act, and, thus, the continuity of the discourse of the identity from where the identity was produced through the historical discontinuity. This discourse against the Brahminical norms and a solid exceptional anti-Brahminic identity would be impossible without the institution of marriage, without its structural repetition - without it being performative.

\section{Performativity of Marriage and Shudra Personhood}

Despite lacking the essence of truth, the Brahminic form of marriage survived because of the institutional force backing the foundation of the marriage and the promises made during the ceremony. Be it priest-craft, institutions like family, temple, and panchayat, ${ }^{13}$ which embodied the Brahminical ideology, enacted promises, the utterances. Similarly, there are certain wishes and promises ${ }^{14}$ made by the bride and groom during a Satyashodhak marriage by making certain performative utterances, such as to show love and devotion to each other, to honour, respect and care for each other and everything created by God, to not discriminate on the basis of caste, race, religion or gender, to respect the dignity of labour and hard work, to not be superstitious, and pursue health, wealth and wisdom with the use of rationality to beget a new generation. The bride demands love, partnership and equality in status from the groom, and the groom, in turn, promises to educate his wife, to be sweet, loving and calm in his behaviour. He also promises honour, dignity and respect for her and to the society and country, and with such utterances of these promises a marriage is solemnised.

\footnotetext{
${ }^{13}$ Village governing structure

${ }^{14}$ See Simple marriages, in Maharashtra Andhashraddha Nirmoolan Samiti. Retrieved September 18, 2020, from https://antisuperstition.org/simple-marriages/
} 
If we think closely, these promises and wishes are fundamental in achieving the personhood of the Shudras. These promises and wishes are essential as they hold an obligation to truth. How would one and the community subvert Brahminical norms and values, if they were not guided by the principles and obligation to those principles? It is especially the obligation to live to the ontological truth that is marriage, which guides the Shudras to act despite the age long slavery and precarity, wherein women are the most vulnerable. These are the performative promises and wishes, producing a sense of obligation, that make marriage an action truth. The bride and groom must actualize the promises and wishes - if not immediately - throughout their lives. And this is where the body goes through an intangible, incorporeal transformation - giving rise to a new sense of personhood. And that very event marks the socio-political transformation of the subject-hood of the Shudras, as it creates a new relationship between the person and the world.

\section{On Achieving Collective Personhood}

To continue this argument, even though the performative promises and wishes stand as an obligation to the truth of marriage, it does not have any truth value to itself. They do not have any verifiability; if anything goes wrong with the performatives, the marriage does not falsify; instead, it turns into an unpleasant marriage or, as Austin (1962) observes, an 'infelicitous act'. Thus, marriage is not merely a communication, between both parties, or between subjects and the world, but it is an institutional form of communication where there exists a mastery over that communication through the process of structural repetition. This is the Derridean notion of structural repetition which gives meaning to marriage and guides or intentionally controls the performative promises and wishes through institutions. The institutions are essential to persuade others through communication to make a collective to continue the structural repetition. For example, Chhatrapati Shahu Ji Maharaj of Kolhapur reportedly organized 200 Satyashodhak marriages without Brahmin priests in 1912, 266 in 1913, and 299 in 1914 (Omvedt, 1976). The institutions of and around marriages turn individual actions and marriages into a collective action - give birth to a collective responsibility and a collective voice. Thus, a collective personhood can also be achieved through that singularized moment of truth between two individuals. So, the collective force is rudimentary in guiding through the incorporeal transformation that happens through the singularized act; to enact the speech of promises and wishes rather than leaving it to the possibility of being rhetoric. This is why I assert that Satyashodhak marriage by the Satyashodhak Samaj was not an unthoughtful choice, instead it was an essential condition in achieving the Shudra personhood as a collective in the most possible sense.

Among one of the Satyashodhak marriages, is the marriage of Balaji Kusaji Patil's son of Junar village: the Brahmin priest denied recognizing the marriage and declared it void as it happened in his absence (Joshi, 1992). In another instance a barber family in Talegaon village was socially boycotted for performing Satyashodhak marriage (Ibid, pp. 53-54). In yet another instance, Jotiba's friend Gyanoba Sasane wished to marry Kasabi the Satyashodhak way, but faced threats and abuses from his immediate family, and the Shudra villagers (Hanlon, 1985, pp. 241-42). In all of the three instances, we can understand that Satyashodhak marriages brought to the fore a sense of visibility of the anti-Brahminic movement. The Satyashodhak marriage is 
essentially a public performance of subverted act to assert the right to autonomous personhood of people who have been denied it. It is an act of self-visibility by those who historically had appearance, but not visibility. It is not about having mere speech, but a voice of those who were socially silenced. It is about asserting sexual rights by people who were either desexualized/hypersexualized or sexually governed. The Satyashodhak marriage, which argued previously to bring some incorporeal transformation, now appears to have brought also some bodily change or movement like the sexual rights and freedom of the Shudras, right to desires and its governance, independent performance rights and their voice. This is why I call it a historical discontinuity on truth - to liberate truth from the deception or untruth of the Brahmins; a new truth about the body and self. People discovered and performed such alliances by discontinuing themselves from the historical (un)truth about themselves.

The rejection of precarity through performance, visibility, voice and essentialization of rights to autonomous personhood has a risk of heightened precarity. As we see, in all these given cases the claim for autonomous personhood constantly faces the threat of violence. This is why institutions and collectives are an essential part of such performance of protest. In the first case the Brahmins had filed a court case against Patil for impinging on their rights. The lower court ruled against Patil initially, but subsequently the higher court ruled in his favour. In the second case, Jotiba advised the barber to discontinue his services to the Brahmins, and in the third case, Jotiba wrote to Ranjan Lingu, a lawyer from Pune and a Satyashodhak member for his help. With Lingu's help police protection was given to Sasane to conduct his marriage.

This leads us to wonder how institutions of law and police enter the sphere of marriage, what is their value or authority over marriage, what is their role in subversion? This also raises another question: if marriage without priest-craft is invalid as the Brahmins assert, does marriage without legal institutions and police become invalid too? We have both yes and no as answers. Yes, because without the law ruling in favour of Patil, the significance of marriage would be questioned as it would be challenged and threatened by violence from forces which are external to law and police. No, because many marriages also happened without facing legal judgments, thus it makes a statement that even if a court ruled against it, the collective force and institutions backing the marriage would still protest for the rights even without having rights to bring subversion in the norms of law. Law and police as external institutions could only defend and justify the act of marriage as authorities, but the otherwise would make law another entity against Shudra personhood, and the protest would continue. Thus, the public performance of independent marriage appears as a protest, i.e., marrying to have the right to be married independently.

If we correctly analyze the situation where Brahmins expected law to be governing and restrictive of the Shudra freedom and personhood, still the law entered the Satyashodhak marriages in a different way. We will understand how, through the movement, the Satyashodhak redefined law as not something to govern and restrict, but to change and protect the marginalized sections and their interests. Such an idea moves law towards a new definition, away from how law is understood as something rigid, bounding, governing, dictating within Brahminism (e.g., Manu's law) towards something where law enters into the discursive realm. It is also very interesting to note how these subversive acts enter into the discursive flow of law, policy and politics, and challenge the normative due to the iterability of the performance - this is where the path for the structural subversion begins - and Jotiba and the Satyashodhaks must 
be credited for leading the path for subversion in structure. Such an idea about law and politics later materialized and has been manifested in the works of anti-caste thinkers and activists like Ambedkar and Kanshiram. Numerous marriages with the help of Chhatrapati Shahu Ji Maharaj and all other Satyashodhaks across Maharashtra stand as evidence of how the subversion of hegemonic Brahminical norms can reproduce new norms, new institutions to achieve the collective personhood.

\section{Conclusion}

I took two events from the art and activism of Jotiba and tried to understand how his work brought about a form of historical discontinuity in truth by first, reaffirming essence and personhood to a precarious body; and second, rejecting precarity in achieving full potential of personhood as a collective. While both goals are opposite to each other, still they are in congruence. And this paradox of opposite goals being in continuity, simultaneously brings out the essence of Jotiba's life: the certain truth about it, his own precarious life for being born as a Shudra and rejection of precarity, and how the second followed the first one, yet it was simultaneous. This paradox can only happen to certain bodies or subjects as their identity and life is produced in the moment of a structural crisis in history - an exceptional moment when one lives both the life of precarity and quest for truth and emancipation at once - simultaneously and together. That moment itself we can think of as the moment of truth happening because no other moment in history can make such a paradox in life happen - where life continues within the social structure and challenges it at the same time. In that very historical moment because that moment is a rupture, a discontinuity and breakthrough - in that moment truth emerges from its invisibility into visibility, to be unconcealed to its full potential, it makes the world aware about its existence and essence, it makes way to enhance the full potential of personhood of human beings.

These are merely two events from Jotiba's life and work, but his work of personhood goes beyond these events. One can analyze from any moment of his life and truth will follow thereafter. This method of research is necessary to save Social Sciences from the binary between banality and essence, which Jotiba himself advocated through his poem on the peasant woman we discussed. In this paper, I have tried to use Jotiba's methodology of discovering essence in the banal life of the peasant woman to argue, similarly, that the banality about Jotiba's life is also what is essential about him. Not because he is an essential figure in our history already, but because our ability to look through the banality or everydayness of his life and find essence in them is what makes him, in turn, an essential figure in history.

Jotiba's everyday, yet exceptional work on education of women, the Shudras and the Ati-Shudras, work against child marriage, female infanticide, widow remarriage, and opening of infanticide prevention centre, widow homes, etc., are other examples of his relentless work towards making liveable the lives of those who were not considered as human as others. The idea of personhood is linked to many rights, such as right to live one's gender, right to sexual freedom, right to education, right to love and to be loved, and the right to achieve full potential as a human being. Jotiba created a collective consciousness through cultural education, the legacy which was taken up by Ambedkar and many other anti-caste philosophers and activists. I must say, Jotiba himself is a fracture in the movement of historical continuity of Brahminism. 


\section{References}

Ambedkar, B. R. (1979). Castes in India: their mechanism, genesis and development. In V. Moon (Ed.), Dr. Babasaheb Ambedkar: writings and speeches, vol. 1. New Delhi: Dr. Ambedkar Foundation.

- (1990). Who were the Shudras? In V. Moon (Ed.), Dr. Babasaheb Ambedkar: writings and speeches, vol. 7. New Delhi: Dr. Ambedkar Foundation.

Austin, J. L. (1962). How to do things with words. Cambridge: Harvard University Press.

BBC News. (2018, September 20). India killing: My father ordered my husband's murder. $B B C$ News, Retrieved on October 26, 2020 from https://www.bbc.com/news/world-asiaindia-45570981

Bhadru, G. (2002). Contribution of Shatyashodhak Samaj to the low caste protest movement in 19th century. Proceedings of the Indian History Congress, 63, pp. 845-854.

Butler, J. (2009). Performativity, precarity and sexual politics. Revista de Antropologia Ileroamericana, 4(3), pp. i-xiii.

Chandrachud, D. Y. (2018, March 8). Shafin Jahan vs. Asokan K. M. Indian Kannon. Retrieved on October 26, 2020 from https://indiankanoon.org/doc/18303067/

Choudhury, S. (2017, November 28). Jyotiba Phule: the method of rational insult. Indian Cultural Forum. Retrieved on September 30, 2020 from https://indianculturalforum.in/2017/11/28/ jyotiba-phule-the-method-of-rational-insult-soumyabrata-choudhury/

Damle, M. (2014). Jotirao Phule: introduction and translation of selected poems. Indian Literature (Sahitya Akademi), 58(1), 10-14.

Derrida, J. (1988). Signature event context. In G. Graff (Ed.), Limited Inc (trans. J. M. Samuel Weber). Evanston, IL: Northwestern University Press, pp. 1-24.

Engels, F., and Untermann, E. (1902). The origin of the family, private property and the state. Chicago: C. H. Kerr \& Co.

Hanlon, Rosalind O. (1985). Caste conflicts and ideology: Mahatma Jotirao Phule and low caste protest in nineteenth century western India, London: Cambridge University Press, pp. 241-242.

Heidegger, M. (1977). The origin of the work of art. In D. Farrell Krell (Ed.), Martin Heidegger: the basic writings (pp. 139-212). San Francisco: HarperCollins.

Joshi, T. Laxmanashastri. (1992). Jotirao Phule - rebel and rationalist of Maharashtra. Kolkata: Renaissance Publication.

Kale, G. (2020). Snapshots from Mahatma Jotirao Phule's life (trans. Sonali Kale and Tejas Harad). in The Satyashodhak. Retrieved September 21, 2020, from https://thesatyashodhak. com/2020/04/17/snapshots-from-mahatma-jotirao-phules-life/

Omvedt, G. (1976). Cultural revolt in a colonial society: the non-brahman movement western India, 1873 to 1930. Bombay: Scientific Socialist Education Trust, 1976.

- (2011). The relevance of Mahatma Phule in today's world: why the "other Mahatma" is more important than Gandhi. Contemporary Voice of Dalit, 4(1), pp. 7-8.

Phule, J. G. (1991). Collected works of Mahatma Jotirao Phule Vol II (trans. P.G. Patil). Education Department, Government of Maharashtra.

- (1991). Slavery (trans. P.G. Patil). Education Department, Government of Maharashtra.

Plato, and Bloom, A. (1968). The Republic. New York: Basic Books. 
Round Table India. (2016, November 26). Babasaheb Dr. B. R. Ambedkar's speech in the Constituent Assembly on 25th November 1949, Round Table India. Retrieved September 16, 2020, from https://roundtableindia.co.in/index.php?option=com_content\&view=artic le\&id=8876:babasaheb-dr-b-r-ambedkar-s-speech-in-the-constituent-assembly-on-25thnovember-1949\&catid $=116 \&$ Itemid $=128$

White, H. (1978). Tropics of discourse: Essays in cultural criticism. Baltimore: Johns Hopkins University Press, pp. 81-100.

- (1980). The value of narrativity in the representation of reality. Critical Inquiry, 7(1). Chicago, IL: University of Chicago Press, pp. 5-27. 